\title{
EFEK PEMBERIAN MATRIX METALLOPROTEINASE-9 (MMP- 9) RNA INTERFERENCE TERHADAP EKSPRESI MMP- 9 PADA KULTUR SEL ENDOTEL VASKULAR
}

\section{THE EFFECT OF MATRIX METALLOPROTEINASE-9 (MMP- 9) RNA ON EXPRESSION IN VASCULAR ENDOTHELIAL MMP-9 SEL LINES}

\author{
Lely Retno Wulandari *, Hidayat Suyuti*, Nadia Artha Dewi*, Safaruddin Refa* \\ * Laboratorium IImu Penyakit Mata Fakultas Kedokteran Universitas Brawijaya/ RSU dr. Saiful Anwar Malang \\ ** Laboratorium Biokimia Biomolekuler Fakultas Kedokteran Universitas Brawijaya
}

\begin{abstract}
Retinal neovascularization is the main problem that causes blindness in many types of eye desease. Neovascularization occurs in ischemic retina, and several important mediators that induce neovascularization is secreted by the surrounding cell and endothelial cell vessels. Matrix metalloproteinase-9 is an enzyme secreted by endothelial cell vessels and plays an important role in the pathogenesis of retinal induce neovascularization. Vascular endothelial cells were cultured and transfected with Matrix Metalloproteinase -9 RNA interference in two doses (100nM or 200nM) and the cells were taken at 24, 48 and 72 hours. The expression of Matrix Metalloproteinase -9 protein levels were examined by immunocytochemistry, and compared with control group. The data were analyzed with factorial anova. Statistical analysis showed that transfection with different doses of MMP-9 RNAi gave a significant different effect on MMP-9 expression ( $p$ value $<0.05)$, while exposure time did not give significant difference ( $p$-value $<0.05)$. This in-vitro study indicated that transfection of MMP-9 RNAi with dose 200nM reduced the expression of MMP-9 by 50\% compared to the control. Because exposure time was not significant, the lowest expression of MMP-9 can be achieved by transfecting MMP-9 RNAi 200nM for 24 hours. This is the first study that demonstrates the effectiveness of RNA interference mediated targeting of MMP-9 to reduce the MMP-9 expression in vascular endothelial cell lines
\end{abstract}

Key Words : Matrix Metalloproteinase -9 - RNA interference - vascular endothelial cell lines.

\section{PENDAHULUAN}

Angiogenesis merupakan suatu proses terbentuknya pembuluh darah baru dari endotel vaskular. Proses angiogenesis sangat penting dalam reproduksi, pertumbuhan dan proses penyembuhan luka. Pada proses tersebut angiogenesis terkontrol dengan baik dimana proses pembentukan pembuluh darah baru akan berlangsung dalam beberapa waktu dan pada saat tertentu prosesnya akan berhenti. Ada beberapa penyakit yang mengakibatkan proses angiogenesis menjadi tidak terkontrol sama sekali. Retinopati diabetika proliferatif, degenerasi makula terkait usia tipe eksudatif, oklusi vena retina sentral dan retinopathy of prematurity seringkali mengakibatkan proses angiogenesis yang tidak terkontrol, hal ini akan mengakibatkan munculnya pembuluh darah baru pada retina dan selanjutnya bisa mengakibatkan kebutaaan. Proses angiogenesis terdiri dari beberapa mekanisme yaitu peningkatan angiogenic growth factor, degradasi matriks ekstra sel, migrasi dan proliferasi sel endotel, pembentukan komponen matriks ekstra sel baru dan diikuti dengan pembentukan pipa kapiler baru.

Jurnal Kedokteran Brawijaya, Vol. XXII, No 2, Agustus 2006

Korespondensi: Lely Retno Wulandari; Laboratorium IImu

Penyakit Mata Fakultas Kedokteran Unibraw/ RSU dr. Saiful Anwar Malang; Jl. Jaksa Agung Suprapto No.2 Malang
Degradasi matriks ekstra sel atau proteolisis merupakan proses penting dalam pembentukan neovaskularisasi sehingga terjadi kerusakan pertahanan anatomi dari pembuluh darah. Pada tahap ini dibutuhkan peranan matrix metalloproteinases (MMPs). Matrix metalloproteinase-9 adalah anggota MMPs kelompok gelatinase yang memiliki keistimewaan yaitu dapat memecah kolagen tipe IV. Kolagen tipe IV sendiri harus dipecah untuk memfasilitasi migrasi sel endotel pembuluh darah. Penelitian sebelumnya oleh Salzmann (2000) didapatkan peningkatan MMP-9 pada neovaskularisasi retina penderita proliferatif diabetika retinopati yang telah dilakukan vitrektomi pars plana (1). Pada penelitian lain oleh Lambert (2002) dan Das (2002) pada model neovaskularisasi retina tikus yang diinduksi iskemia ditemukan peranan MMP-9 dalam pembentukan neovaskularisasi khoroid $(2,3)$. Selain itu diduga bahwa inhibisi MMP-9 lebih efektif dalam mencegah dan menghentikan angiogenesis patologis pada kelainan retina iskemik $(2,4)$.

Akhir - akhir ini revolusi dalam ilmu biologi telah menemukan terobosan baru, suatu metode RNA interference (RNAi). Metode RNAi merupakan mekanisme baru untuk menghentikan proses transkripsi dengan cara mengaktifasi proses degradasi messenger RNA (mRNA). 
Regulasi ekspresi gen pada beberapa organisme dan atau sel dengan metode ini mempunyai efektifitas yang sangat tinggi dan relatif mudah dilakukan. Aspek klinis RNAi pada penyakit adalah terjadinya hambatan dari satu atau beberapa protein sehingga terjadi perlambatan atau penghentian proses penyakit pada sel yang terpengaruh RNAi. RNAi secara umum didefinisikan sebagai fenomena penting dalam Post Transcriptional Gene Silencing (PTGS). Tahap berikutnya dalam perkembangan teknologi RNAi ditujukan pada target gen yang menginduksi angiogenesis. Dari uraian di atas terbukti MMP-9 berperan serta dalam angiogenesis. MMP-9 yang meningkat akan menimbulkan kerusakan pertahanan anatomi pembuluh darah, sehingga MMP-9 adalah target yang cukup ideal untuk penghambatan proses angiogenesis.

Pada penelitian ini akan diteliti efek pemberian MMP9 RNAi terhadap ekspresi MMP-9 pada kultur sel endotel vaskular, dan selanjutnya akan diteliti dosis efektif MMP-9 RNAi dan efek lamanya jangka waktu paparan MMP-9 RNAi dalam menurunkan ekspresi MMP-9. Dipergunakannya sel endotel vaskular umbilikus sebagai sampel pada penelitian ini adalah oleh karena secara umum sel endotel vaskular umbilikus mempunyai sifat yang mirip dengan endotel retina dan sel endotel vaskular umbilikus banyak dipakai sebagai model penelitian untuk proses terjadinya neovaskularisasi retina $(5,6)$.

\section{METODE}

Penelitian ini merupakan penelitian eksperimental dengan sampel kultur sel endotel vaskular umbilikus manusia. Penelitian dilakukan di Laboratorium Fisiologi Universitas Brawijaya. Waktu penelitian bulan Januari 2006 sampai Juli 2006. Penelitian ini melibatkan dua variabel yaitu :

Variabel bebas : MMP-9 RNAi

Variabel terikat : Ekspresi MMP-9.

\section{Pembuatan kultur sel endotel vaskular umbilikus manusia.}

\section{Pengambilan Umbilikus}

Umbilikus diperoleh dari kamar operasi Rumah Sakit Saiful Anwar Malang dari ibu yang tidak menderita hipertensi, anemia dan diabetes mellitus. Disiapkan botol berisi cord solution dari refrigerator (suhu $4{ }^{\circ} \mathrm{C}$ ). Metode pembuatan medium cord solution adalah sebagai berikut :

Diambil $10 \mathrm{ml} \mathrm{HBSS}$ dan tambahkan $90 \mathrm{ml}$ deionized water, $3,75 \mathrm{ml}$ bicarbonate phenol red, 2,5 ml larutan HEPES, 1,25 $\mathrm{ml}$ gentamycine. Diukur pH pada 7,4 (warna menyerupai HBSS pekat). Sterilisasi dengan filter $0,2 \mu \mathrm{m}$. Disimpan dalam refrigerator suhu $4^{\circ} \mathrm{C}$. Segera setelah kelahiran, umbilikus dipotong sepanjang $\pm 20 \mathrm{~cm}$ dan langsung dimasukkan medium cord solution. Pengerjaan kultur sel endotel tidak melebihi 12 jam setelah waktu kelahiran.

\section{Isolasi dan pembuatan kultur sel endotel vaskular umbilikus manusia}

Umbilikus dibersihkan dari jaringan dan bekuan darah yang ada dengan kertas tissue yang disemprot dengan alkohol $70 \%$. Masing-masing ujung umbilikus dipotong transversal sehingga terlihat dua arteri dan satu vena. Vena akan terlihat mempunyai dinding yang lebih tebal, lebih besar dan elastis. Kanula dimasukkan pada salah satu ujung vena $( \pm 1 \mathrm{~cm})$, kemudian diikat erat dengan benang. Vena dibersihkan / dibilas dengan $10 \mathrm{ml}$ larutan PBSA melalui kanula yang telah terpasang dengan spuit 20 cc. Setelah bersih, ikat ujung umbilikus yang lain dengan ikatan yang kuat (atau diklem).

Larutan collagenase dimasukkan dan spuit dibiarkan menancap pada kanula. Selanjutnya umbilikus dihangatkan dengan cara didekap dengan kedua belah tangan dan didekatkan dengan Bunsen (agar mencapai suhu $\sim 37^{\circ} \mathrm{C}$ ) selama 7 menit. Collagenase (yang telah mengandung endotel) dikeluarkan dari umbilikus dengan cara menyedot melalui spuit yang masih terpasang pada ujung kanula. Kemudian collagenase tersebut dimasukkan pada tabung sentrifuge steril $15 \mathrm{cc}$.Umbilikus dibilas dengan $8 \mathrm{cc}$ larutan PBSA untuk membilas sel endotel yang masih tersisa. Kemudian larutan disedot kembali dan ditambahkan ke dalam tabung sentrifuge yang berisi larutan collagenase.Larutan yang telah mengandung sel endotel tersebut disentrifugasi dengan kecepatan $10.000 \mathrm{rpm}$ selama 8 menit. Supernatan dibuang, kemudian ditambahkan $4 \mathrm{ml}$ medium kultur M199 pada pellet dan diresuspensi dengan cara pipetting sehingga sel-sel endotel terpisah.

Larutan dipindahkan ke dalam plate 24 well yang sebelumnya telah dilapisi dengan larutan gelatin $0,2 \%$, kemudian dimasukkan pada inkubator $\mathrm{CO}_{2} 5 \%$ pada suhu $37 \circ$ C selama 20 menit. Plate 24 well diambil dan sel endotel diamati dengan mikroskop inverted perbesaran 400x. Jika sel sudah menempel pada dasar flask, medium kultur diambil dan sel dibilas dengan $3 \mathrm{ml}$ serum free medium 3 melalui filter $0,2 \mu \mathrm{m}$. Serum free medium diambil dengan spuit steril dan digantikan dengan medium kultur (M199 dan FCS 10\%) $4 \mathrm{ml}$ melalui filter 0,2 $\mu \mathrm{m}$. Flask dimasukkan ke dalam inkubator sampai monolayer (membentuk cobblestone) kurang lebih 3-4 hari dan medium diganti setiap 2 hari sekali.

\section{Transfeksi dengan MMP-9 RNAi}

MMP-9 RNAi diperoleh dari coding sequence dari gen MMP-9 manusia. Pemilihan siRNA berdasar pada program Ambion. Kultur sel endotel vaskular umbilikus di transfeksi dengan menggunakan MMP-9 RNAi dengan konsentrasi akhir 100 dan 200 nM Untuk setiap well yang 
berisi $500 \mu \mathrm{l}$ medium kultur diberikan campuran OptiMEM $50 \mu \mathrm{l}$ dan RNAi sesuai dosis. Medium diganti12 jam kemudian. Kontrol negatif tidak ditransfeksi dengan MMP-9 RNAi. Fiksasi dilakukan setelah 24, 48 dan 72 jam pemberian transfeksi untuk dianalisa. Kontrol negatif juga dianalisa. Prosedur dilakukan triplikat untuk melihat reproducibility

\section{Pemeriksaan imunositokimia}

Kultur sel endotel masing-masing perlakuan difiksasi dengan metanol selama 20 menit. Sel dicuci dengan phospat buffered saline (PBS) pH 7,4 sebanyak 3 kali selama masing-masing 5 menit. Sel ditetesi dengan 0,02\% sodium azide. Dicuci menggunakan PBS pH 7,4 sebanyak 3 kali, masing-masing selama 5 menit. Sel ditetesi dengan larutan $\mathrm{H}_{2} \mathrm{O}_{2}$ dalam PBS selama 10 menit. Sel ditetesi dengan blocking serum dengan Bovine Serum Albumine (BSA) 0,25 \% (w/v) selama 1 jam. Sel dicuci dengan PBS. Inkubasi antibodi primer anti human MMP-9 dalam serum 1 : 250 selama 24 jam. Sel disimpan pada suhu $4{ }^{\circ} \mathrm{C}$. Jaringan dikeluarkan pada suhu ruang selama 15 menit. Sel dicuci dengan PBS 3 kali selama masing-masing 5 menit. Sel diinkubasi dengan antibodi sekunder anti rabbit 1:500 selama 1 jam pada suhu ruang. Sel dicuci dengan PBS 3 kali selama masing-masing 5 menit. Sel ditetesi dengan SA-HRP selama 40 menit kemudian dicuci dengan PBS 3 kali selama masing-masing 5 menit. Sel ditetesi dengan Diamino Benzidine (DAB) dalam buffer

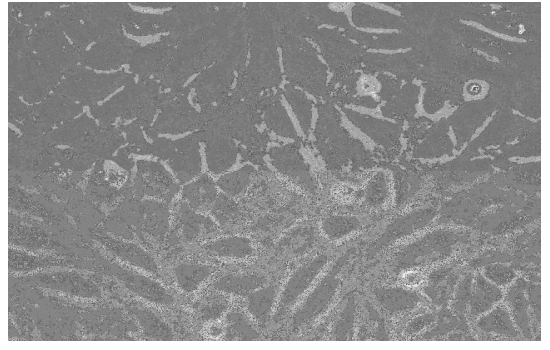

Gambar 1. Hasil kultur endotel Vaskular sebelum mengalami perlakuan

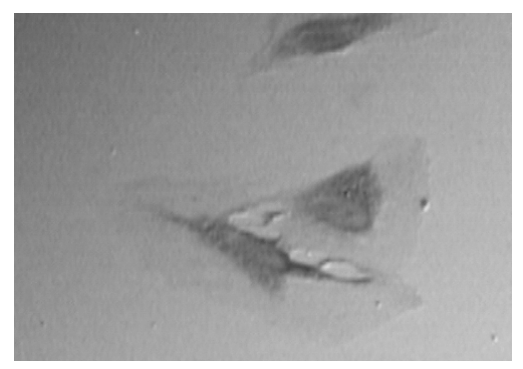

Gambar 4. Ekspresi MMP-9 pada sel endotel vaskuler tanpa pemberian MMP-9 RNAi waktu pengamatan 24 jam

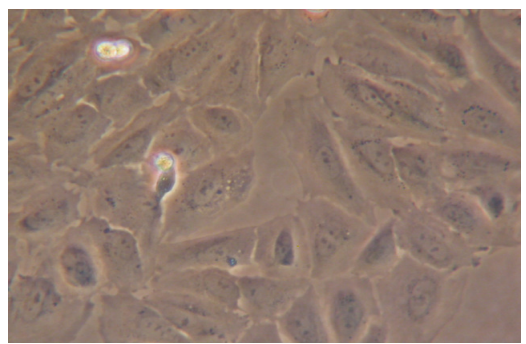

Gambar 2. Kultur sel endotel vaskuler setelah transfeksi dengan $100 \mathrm{Nm}$ MMP-9 RNAi

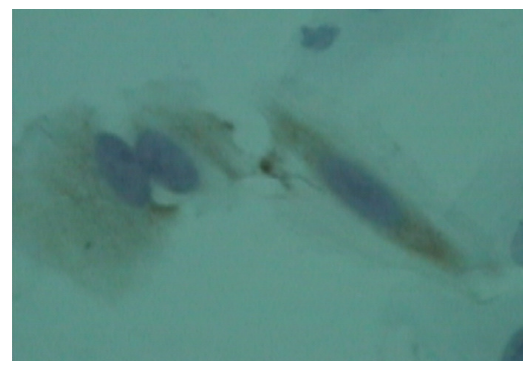

Gambar 5. Ekspresi MMP-9 pada sel endotel vaskuler tanpa pemberian MMP-9 RNAi waktu pengamatan 48 jam

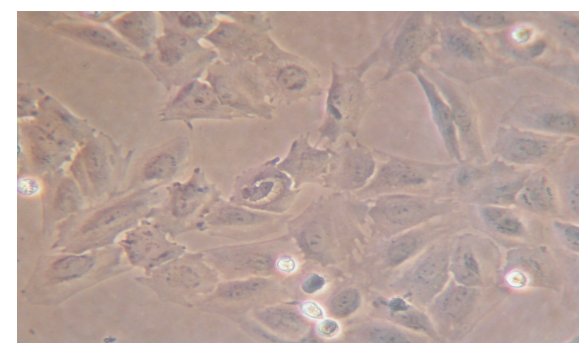

Gambar 3. Kultur sel endotel vaskuler setelah transfeksi dengan $200 \mathrm{Nm}$ MMP-9 RNAi

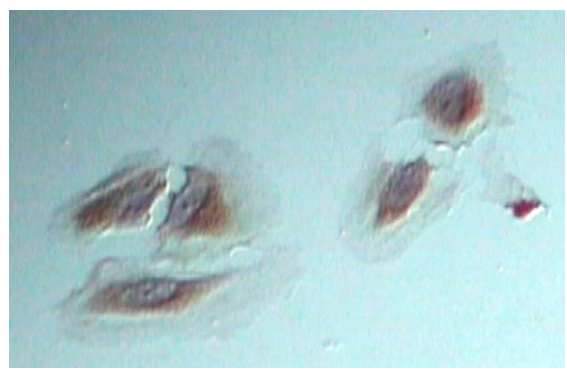

Gambar 6. Ekspresi MMP-9 pada sel endotel vaskuler tanpa pemberian MMP-9 RNAi waktu pengamatan 72 jam 
Sel endotel vaskular setelah transfeksi dengan dosis 100 nM MMP-9 RNAi dan pengecatan immunositokimia dengan anti MMP-9 antibodi disajikan dalam Gambar 7,8\&
9. Sel endotel vaskular setelah transfeksi dengan dosis 200 nM MMP-9 RNAi dan pengecatan immunositokimia dengan anti MMP-9 antibodi disajikan dalam Gambar 10,11 dan 12.

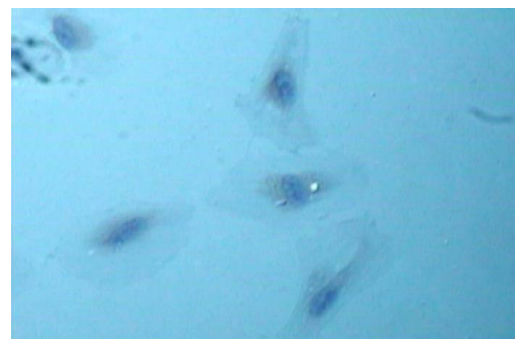

Gambar 7. Ekpresi MMP-9 pada sel endotel vaskuler setelah transfeksi $100 \mathrm{Nm}$ MMP-9 RNAi waktu pengamatan 24 jam

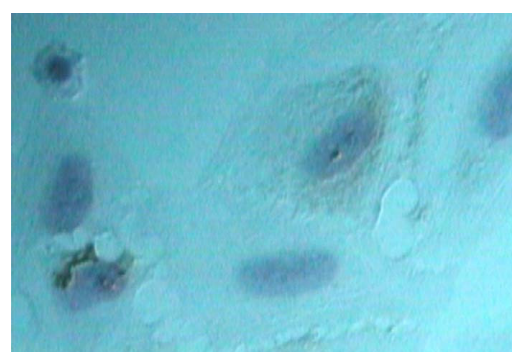

Gambar 10. Ekspresi MMP-9 pada sel endotel vaskuler setelah transfeksi $200 \mathrm{Nm}$ MMP-9 RNAi waktu pengamatan 24 jam

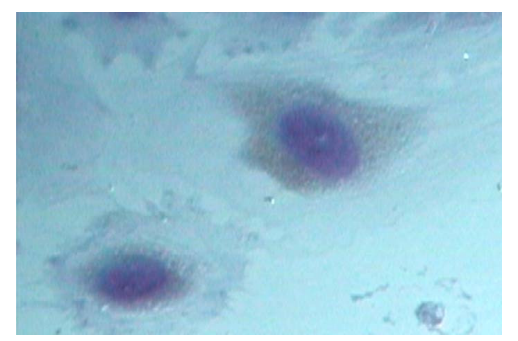

Gambar 8. Ekpresi MMP-9 pada sel endotel vaskuler setelah transfeksi 100 Nm MMP-9 RNAi waktu pengamatan 48 jam

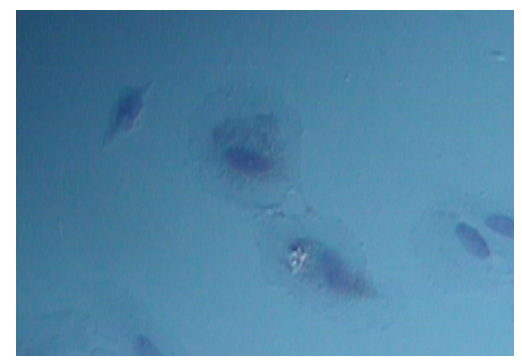

Gambar 11. Ekspresi MMP-9 pada sel endotel vaskuler setelah transfeksi 200 Nm MMP-9 RNAi waktu pengamatan 48 jam

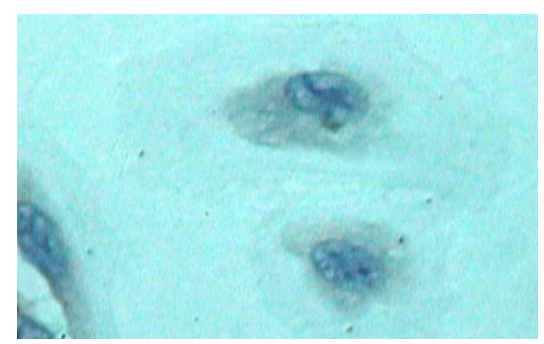

Gambar 9. Ekpresi MMP-9 pada sel endotel vaskuler setelah transfeksi $100 \mathrm{Nm}$ MMP-9 RNA waktu pengamatan 72 jam

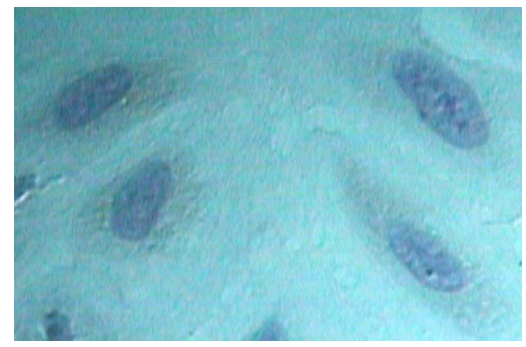

Gambar 12. Ekspresi MMP-9 pada sel endotel vaskuler setelah transfeksi $200 \mathrm{Nm}$ MMP-9 RNAi waktu pengamatan 72 jam
Deskripsi data dasar hasil penelitian setelah melakukan pengamatan masing-masing sebanyak 3 kali pada kombinasi 3 level faktor dosis dan 3 level faktor waktu disajikan dalam tabel berikut. Pengamatan dilakukan terhadap jumlah sel dengan ekspresi MMP-9 baik yang positif dan negatif. Ekspresi MMP-9 dilihat berdasarkan teknik immunositokimia. Deskripsi sel dengan ekspresi MMP-9 positif dari 9 perlakuan ditampilkan berdasarkan nilai minimum, maksimum, rata-rata dan standard deviasi.

Tabel 1. Data Dasar Statistik Deskriptif Ekspresi MMP-9 Pada Kombinasi Faktor Dosis dan Waktu

\begin{tabular}{clcccc}
\hline Dosis & Waktu & Minimum & Maksimum & Rata-rata & Std. Deviasi \\
\hline \multirow{2}{*}{ Kontrol } & 24 jam & 56,52 & 77,27 & 68,41 & 10,70 \\
& 48 jam & 75,00 & 86,96 & 80,97 & 5,98 \\
100 nM & 72 jam & 65,52 & 84,38 & 74,96 & 9,43 \\
MMP-9 & 24 jam & 52,94 & 67,86 & 59,87 & 7,51 \\
RNAi & 72 jam & 56,52 & 66,67 & 62,27 & 5,21 \\
200 nM & 24 jam & 63,64 & 69,57 & 65,97 & 3,16 \\
MMP-9 & 48 jam & 20,75 & 58,33 & 42,36 & 20,87 \\
RNAi & 72 jam & 28,57 & 45,45 & 33,82 & 12,87 \\
\hline
\end{tabular}


Dari data dasar statistik deskriptif diatas, pemberian dosis 100 nM MMP-9 RNAi akan menurunkan ekspresi MMP-9 hingga pada kisaran 34,03 \% - 40,13 \%. Sedangkan MMP-9 RNAi dengan dosis 200nM akan menurunkan ekspresi MMP-9 hingga pada kisaran 57,64 \% - 66,37\%. Perbedaan waktu pemberian MMP-9 RNAi belum menunjukkan perbedaan ekspresi sel MMP yang tajam. Secara grafik hubungan antara sel dengan ekspresi MMP-9 positif dengan faktor dosis dan waktu dapat dilihat pada Grafik 1 dan Grafik 2 berikut ini.

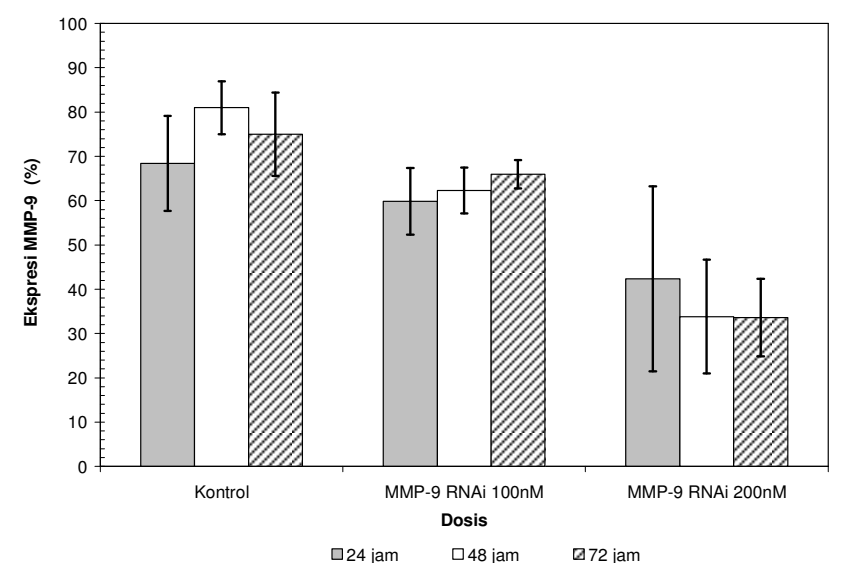

\section{Grafik 1. Hubungan Dosis dengan Ekpresi MMP-9 Berdasarkan Faktor Waktu}

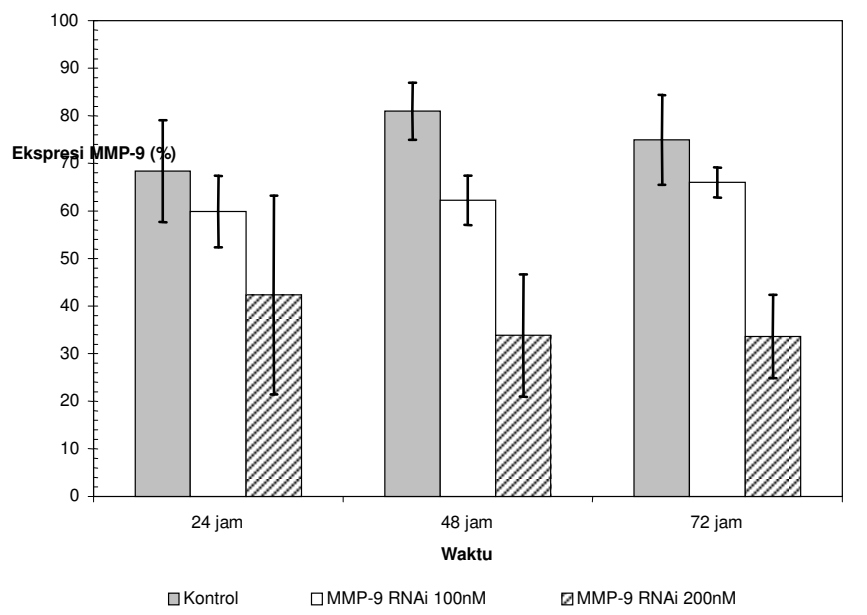

Grafik 2. Hubungan Dosis dengan Ekpresi MMP-9 Berdasarkan Faktor Dosis

Efek akibat perbedaan dosis dan waktu pemberian MMP-9 RNAi dalam menurunkan ekspresi MMP-9 pada kultur sel endotel vaskular

Efek akibat perbedaan dosis dan waktu pemberian MMP-9 RNAi dalam menurunkan ekspresi MMP-9 pada kultur sel endotel vaskular dapat dilihat melalui analisa statistik dengan metode anova faktorial. Sebelum dilakukan uji statistik dengan anova hasil penelitian harus memenuhi uji statistik tertentu. Metode statistik anova memiliki beberapa asumsi yang harus dipenuhi, antara lain ragam perlakuan adalah harus homogen dan data residual harus berdistribusi normal Pengujian homogenitas ragam dilakukan dengan uji Levene sedangkan pengujian distribusi data residual dilakukan dengan uji Kolmogorov Smirnov. Hasil dari uji Levene menghasilkan nilai F sebesar 2,200 ( $p$ value $=0,079$ ) yang memberikan kesimpulan bahwa nilai ragam ekspresi MMP-9 dari 9 perlakuan pada penelitian ini secara statistik adalah homogen. Sedangkan hasil uji Kolmogorov-Smirnov distribusi normal dengan nilai $Z$ sebesar 0,378 ( $p$-value $=0,999$ ) telah memberikan kesimpulan bahwa nilai residual berdistribusi normal.

Selanjutnya efek akibat perbedaan dosis dan waktu pemberian MMP-9 RNAi terhadap ekspresi MMP-9 dilakukan dengan analisis ragam faktorial. Hasil pengujian terdiri atas dua bagian, pertama membuktikan adanya efek dari perlakuan utama yaitu faktor dosis atau waktu terhadap ekspresi MMP-9 dan kedua efek dari interaksi dosis dan waktu terhadap ekspresi MMP-9. Tabel 2 berikut adalah hasil anova faktorial.

\section{Tabel 2. Hasil Anova Faktorial Ekspresi MMP-9}

\begin{tabular}{cccccc}
\hline $\begin{array}{c}\text { Sumber } \\
\text { Keragaman }\end{array}$ & $\begin{array}{c}\text { Jumlah } \\
\text { Kuadrat }\end{array}$ & $\begin{array}{c}\text { Derajat } \\
\text { Bebas }\end{array}$ & $\begin{array}{c}\text { Kuadrat } \\
\text { Tengah }\end{array}$ & F & $\begin{array}{c}p- \\
\text { falue }\end{array}$ \\
\hline Dosis & 6853,875 & 2 & 3426,938 & 30,521 & 0,000 \\
Waktu & 20,946 & 2 & 10,473 & 0,093 & 0,911 \\
Interaksi & 421,706 & 4 & 105,427 & 0,939 & 0,464 \\
Galat & 2021,036 & 18 & 112,280 & & \\
Total & 9317,563 & 26 & & & \\
\hline
\end{tabular}

Hasil anova faktorial menjelaskan bahwa perbedaan pemberian dosis MMP-9 RNAi memiliki efek yang bermakna terhadap ekspresi MMP-9 ( $p$-value $<0,05)$, sedangkan efek dari waktu tidak memberikan efek yang bermakna ( $p$-value $>0,05)$. Hasil anova faktorial juga menyatakan bahwa interaksi antara dosis dan waktu pemberian MMP-9 RNAi adalah tidak bermakna ( $p$-value $>0,05)$. Pengaruh interaksi antara dosis dan waktu pemberian MMP-9 RNAi yang tidak bermakna menunjukkan bahwa pemberian MMP-9 RNAi pada waktu yang berbeda memiliki pola yang sama. 


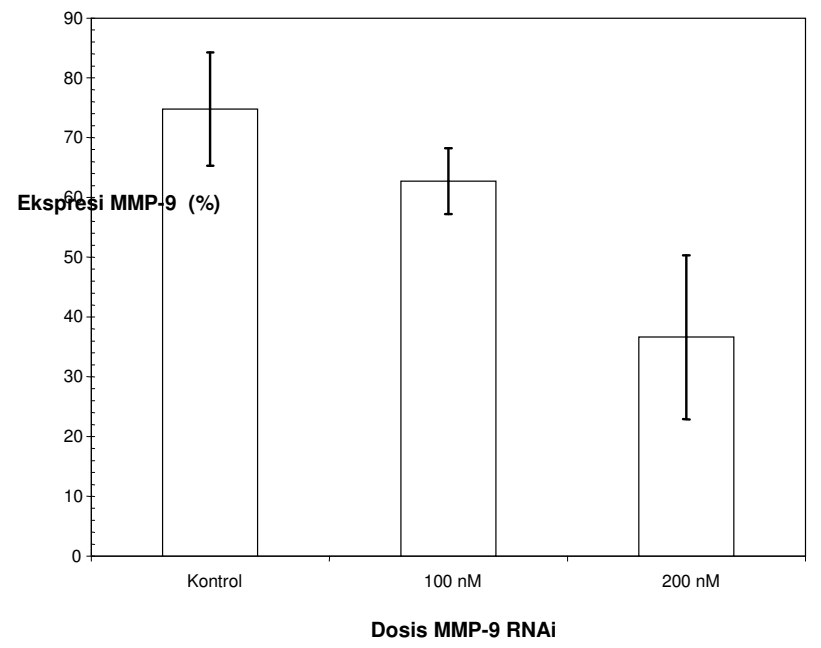

Grafik 3. Efek faktor dosis pemberian MMP-9 RNAi terhadap ekspresi MMP-9

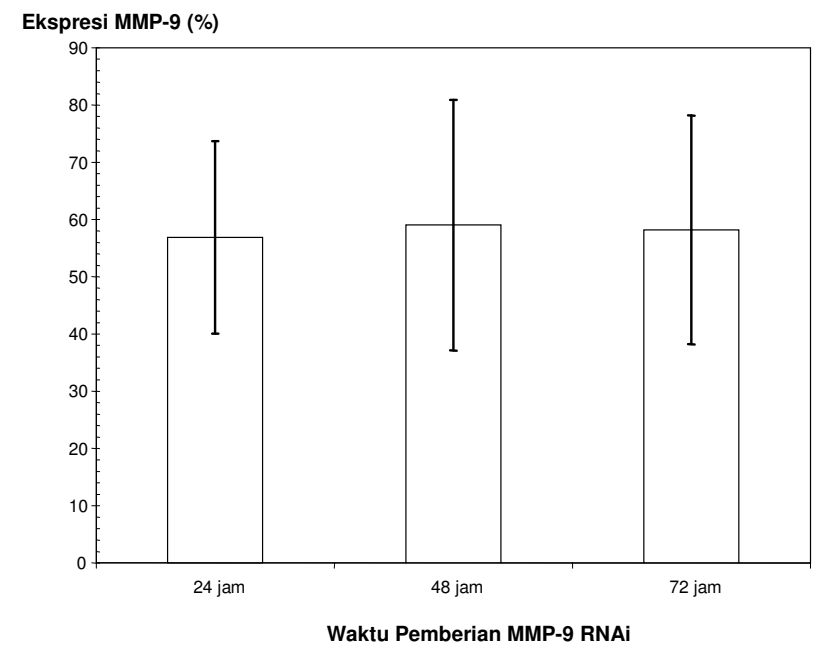

Grafik 4. Efek faktor waktu pemberian MMP-9 RNAi terhadap ekspresi MMP-9

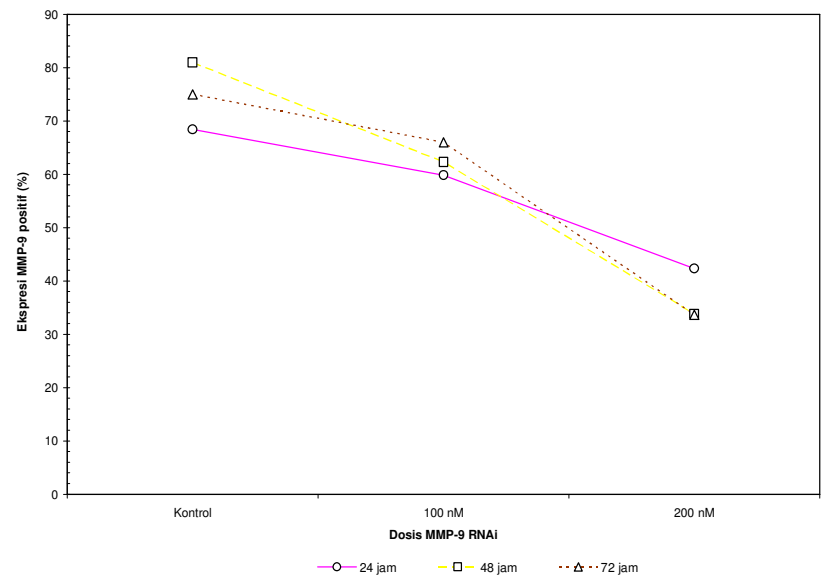

Grafik 5. Efek interaksi faktor dosis dan waktu pemberian MMP-9 RNAi terhadap ekspresi MMP-9
Berdasarkan Grafik 3 dan Grafik 5 tampak jelas bahwa peningkatan dosis MMP-9 RNAi akan mengakibatkan penurunan ekspresi MMP-9. Sedangkan waktu papara RNAi tidak banyak berpengaruh terhadap penurunan ekspresi MMP9 (Grafik 4). Penurunan jumlah ekspresi MMP-9 pada dosis MMP-9 RNAi yang berbeda dilanjutkan dengan uji beda nyata terkecil (BNJ) seperti pada tabel 3 berikut ini. Hasil uji BNJ dapat menunjukkan dosis efektif pemberian MMP-9 RNAi.

Tabel 3. Hasil Uji BNJ Rata-rata Ekspresi MMP-9 pada Faktor Dosis

\begin{tabular}{ccc}
\hline Dosis & Rata-rata & Notasi \\
\hline kontrol & 74,781 & $\mathrm{~b}$ \\
100 nM MMP-9 RNAi & 62,706 & $\mathrm{~b}$ \\
200 nM MMP-9 RNAi & 36,603 & $\mathrm{a}$ \\
\hline
\end{tabular}

Keterangan : Rata-rata dengan notasi huruf yang sama berarti tidak berbeda bermakna pada $\alpha=0,05$

Berdasarkan hasil uji BNJ, secara statistik belum diperoleh perbedaan yang bermakna antara rata-rata ekspresi MMP-9 pada perlakuan kontrol dengan pemberian MMP-9 RNAi dosis $100 \mathrm{nM}$. Rata-rata ekspresi MMP-9 untuk kontrol adalah $74,781 \%$ sedangkan rata-rata ekspresi MMP-9 pada dosis 100 nM MMP-9 RNAi adalah 62,706\%. Rata-rata ekspresi MMP-9 pada dosis 200 nM MMP-9 RNAi adalah sebesar $36,603 \%$ dimana hal ini menunjukkan penurunan sebesar $50 \%$ dibandingkan kontrol. Berdasarkan hasil uji BNJ, secara statistik telah didapatkan hasil yang bermakna yaitu dengan pemberian dosis 200 nM MMP-9 RNAi telah memberikan penurunan ekspresi MMP-9 sebesar $50 \%$ daripada kontrol. Karena efek dari faktor waktu adalah tidak bermakna, maka untuk menghasilkan ekspresi MMP-9 yang paling rendah dapat dilakukan dengan memberikan MMP-9 RNAi pada dosis 200 nM dan pada waktu 24 jam.

\section{DISKUSI}

Matrix metalloproteinase - 9 merupakan anggota dari kelompok matrix metalloproteinases yang memiliki keistimewaan yaitu dapat memecah kolagen tipe IV. Kolagen tipe IV harus dipecah terlebih dahulu untuk memfasilitasi migrasi sel endotel pembuluh darah $(2,7)$.

Berdasarkan penelitian sebelumnya oleh Salzmann (2000) didapatkan peningkatan MMP-9 pada neovaskularisasi retina penderita proliferatif diabetika retinopati yang telah dilakukan vitrektomi pars plana (1). Pada penelitian lain oleh Lambert (2002) dan Das (2002) pada model neovaskularisasi retina tikus yang diinduksi iskemia ditemukan peranan MMP-9 dalam pembentukan neovaskularisasi khoroid $(2,3)$. Selain itu diduga bahwa inhibisi MMP-9 lebih efektif dalam mencegah dan 
menghentikan angiogenesis patologis pada kelainan retina iskemik $(6,8)$.

Terapi yang diberikan pada proses angiogenesis patologis bertujuan untuk menghambat stimulus atau jalur efektor, tetapi jika penyebab stimulus tidak diketahui maka jalur efektor merupakan target menarik untuk dilakukan intervensi, dan selanjutnya terapi ini akan menghambat terjadinya proses angiogenesis. Peranan MMP-9 dalam proses morfogenesis kapiler baru, merupakan final common pathway (jalur efektor). Inhibisi pada level ini lebih menarik daripada inhibisi target individu (seperti VEGF,FGF, Angiopietin) karena meskipun inhibisi ini lebih efektif, tetapi masih ada kemungkinan neovaskularisasi disebabkan oleh growth factor yang lain (9).

Pada penelitian ini dilakukan inhibisi MMP-9 dengan pendekatan metode RNAi untuk menurunkan mRNA MMP-9 pada kultur sel endotel vaskular, dengan asumsi bila terjadi penurunan mRNA MMP-9, diharapkan juga akan terjadi penurunan ekspresi MMP-9 sehingga secara tidak langsung menghambat proses angiogenesis. Tidak ada penelitian sebelumnya yang membuktikan efektifitas pemberian RNAi dalam menghambat ekspresi MMP-9 pada endotel vaskular baik secara in vitro maupun in vivo.

Pada penelitian ini telah diteliti tentang efek pemberian MMP-9 RNAi terhadap ekspresi MMP-9 pada kultur sel endotel vaskular. Penelitian ini menggunakan sel endotel vaskular umbilikus sebagai sampel oleh karena sel endotel vaskular umbilikus mempunyai sifat yang mirip dengan sel endotel retina dan sel endotel vaskular umbilikus banyak dipakai sebagai model penelitian untuk proses terjadinya neovaskularisasi retina. Sel endotel vaskular umbilikus diambil dari ibu yang tidak menderita hipertensi, anemia dan diabetes mellitus. Alasan mengapa umbilikus dari ibu yang menderita hipertensi, anemia dan diabetes mellitus tidak digunakan dalam penelitian ini adalah tingginya resiko kegagalan pada saat membuat kultur sel endotel vaskular.

Setelah kultur sel endotel vaskular ditransfeksi dengan pemberian dua dosis MMP-9 RNAi (100 nM atau $200 \mathrm{nM}$ ) dilakukan pengambilan sampel pada jam ke-24, jam ke-48 dan jam ke-72. Kemudian setelah pengecatan immunositokimia ekspresi MMP-9 dianalisa. Hasil yang didapat dibandingkan dengan kelompok kontrol yang tidak mengalami perlakuan apapun. Dari Gambar 1 didapatkan hasil kultur sel endotel vaskular cukup optimal dengan menggunakan teknik kolagenase, dimana dengan teknik ini didapatkan sel endotel yang monolayer.

Kondisi sel yang monolayer ini penting untuk keberhasilan proses transfeksi dari MMP-9 RNAi, permukaan sel yang luas memudahkan kontak antara RNAi dengan sel.

Gambar 2 dan 3 menunjukkan sel endotel vaskular tetap sehat (viable) setelah perlakuan transfeksi RNAi.
Secara teoritis dikatakan bahwa optiMEM dan perlakuan transfeksi RNAi dapat memberikan efek toksik dan menimbulkan efek kematian sel, akan tetapi pada penelitian ini didapatkan sel yang tetap sehat dikarenakan dilakukan penggantian medium 12 jam setelah transfeksi.

Awalnya pada penelitian ini sebelum perlakuan transfeksi RNAi direncanakan untuk memberikan perlakuan hipoksia pada sel endotel vaskular dengan tujuan untuk meningkatkan ekspresi MMP-9. Akan tetapi dari percobaan pendahuluan didapatkan bahwa ekspresi MMP-9 cukup banyak walaupun pada kondisi normal tanpa hipoksia. Oleh karena itu penelitian ini dilakukan tanpa perlakuan hipoksia dan diharapkan pemberian RNAi yang menurunkan ekspresi MMP-9 masih dapat diobservasi. Pada Gambar 4 , 5 dan 6 didapatkan ekspresi MMP-9 yang cukup banyak pada sel kontrol/ tanpa perlakuan RNAi. Dari gambar disini terlihat jelas penampakan sel yang kecoklatan setelah pengecatan immunositokimia.

Pemberian MMP-9 RNAi dengan dosis $100 \mathrm{nM}$ menurunkan ekspresi MMP-9, dimana hal ini digambarkan dari menurunnya/ menghilangnya warna kecoklatan dari sel endotel vaskular setelah pengecatan immunositokimia (Gambar 7, 8 dan 9). Penurunan ini semakin nyata setelah pemberian MMP-9 RNAi dengan dosis 200nM (Gambar 10, 11 dan 12 ).

Dari penelitian yang telah dilakukan didapatkan data hasil penelitian yang homogen sesuai dengan uji Lavene dan berdistribusi normal sesuai dengan uji KolmogorovSmirnov. Sehingga selanjutnya data hasil penelitian dapat diuji dengan metode statistik anova. Efek akibat perbedaan dosis dan waktu pemberian MMP-9 RNAi terhadap ekspresi MMP-9 dilakukan dengan anova faktorial.

Hasil anova faktorial menjelaskan bahwa perbedaan pemberian dosis MMP-9 RNAi memiliki efek yang bermakna terhadap ekspresi MMP-9 ( $p$-value $<0,05)$, sedangkan efek dari waktu pemberian MMP-9 RNAi dan interaksi antara dosis dan waktu belum memberikan efek yang bermakna ( $p$-value $>0,05$ ).

Sumber keragaman pada penelitian ini yang mempengaruhi ekspresi MMP-9 ini adalah faktor dosis, faktor waktu, faktor interaksi antara dosis dan waktu serta faktor galat. Faktor galat merupakan faktor lain yang tidak dapat dijelaskan tetapi memberi efek terhadap ekspresi MMP-9. Oleh karena penelitian ini adalah seragam (sampel dan perlakuan adalah sama) sulit menjelaskan adanya faktor lain yang dapat memberikan efek terhadap ekspresi MMP-9. Kemungkinan faktor galat pada penelitian ini dapat disebabkan oleh adanya faktor perbedaan luas permukaan masing-masing sel sehingga proses kontak dengan MMP-9 RNAi menjadi berbeda, atau adanya perbedaan siklus masing-masing sel saat menerima transfeksi MMP-9 RNAi sehingga ekspresi MMP-9 yang dihasilkan juga berbeda. 
Grafik 5 menunjukkan tidak adanya interaksi antara dosis dan waktu pemberian MMP-9 RNAi. Grafik ini menunjukkan tiga garis yang kongruen dan tidak ada interaksi. Pengaruh interaksi antara dosis dan waktu pemberian MMP-9 RNAi yang tidak bermakna memiliki arti bahwa efek pemberian MMP-9 RNAi pada waktu yang berbeda memiliki pola yang sama. Jika interaksi antara dosis dan waktu pemberian MMP-9 RNAi memiliki efek bermakna maka akan memudahkan pengaplikasian hasil penelitian ini pada penelitian selanjutnya.

Untuk menentukan dosis efektif MMP-9 RNAi telah dilakukan uji BNJ. Berdasarkan hasil uji BNJ, secara statistik telah didapatkan hasil yang bermakna yaitu dengan pemberian MMP-9 RNAi dengan dosis $200 \mathrm{nM}$ telah memberikan penurunan ekspresi MMP-9 sebesar 50\% daripada kontrol.

Oleh karena hasil penelitian menunjukkan efek dari faktor waktu adalah tidak bermakna, maka untuk menghasilkan ekspresi MMP-9 yang paling rendah dapat dilakukan dengan memberikan RNAi pada dosis $200 \mathrm{nM}$ dan waktu 24 jam.

Dari pembahasan diatas dapat ditarik kesimpulan bahwa hipotesa penelitian yang menyatakan bahwa pemberian MMP-9 RNAi akan menurunkan ekspresi MMP-9 pada kultur sel endotel vaskular dapat diterima. Oleh karena itu penelitian mengenai MMP-9 RNAi yang lebih mengarah ke aplikasi klinis diharapkan dapat dilanjutkan setelah penelitian ini.

\section{KESIMPULAN}

Berdasarkan hasil penelitian yang dilakukan, dapat disimpulkan bahwa efek pemberian MMP-9 RNAi akan menurunkan ekspresi MMP-9 pada kultur sel endotel vaskular. Dosis efektif MMP-9 RNAi dalam menurunkan ekspresi MMP-9 pada kultur sel endotel vaskular adalah 200 nM. Waktu efektif paparan MMP-9 RNAi dalam menurunkan ekspresi MMP-9 pada kultur sel endotel vaskular adalah 24 jam.

\section{SARAN}

Penelitian ini adalah penelitian pertama yang membuktikan efektifitas pemberian RNAi dalam menurunkan ekspresi MMP-9 pada sel endotel vaskular umbilikus secara in vitro. Sel endotel vaskular umbilikus dipakai sebagai model penelitian ini oleh karena kemiripan sifatnya dengan sel endotel vaskular retina. Hasil penelitian ini sebaiknya dipakai sebagai dasar penelitian selanjutnya tentang efek MMP-9 RNAi terhadap proses angiogenesis di mata terutama pada retina, efek MMP-9 RNAi terhadap ekspresi MMP-9 pada proses kelainan penyakit-penyakit mata lain yang melibatkan MMP-9 dan efek MMP-9 RNAi terhadap ekspresi MMP-9 pada penyakit-penyakit organ lain yang melibatkan MMP-9. Penelitian mengenai MMP-9 RNAi yang lebih mengarah ke aplikasi klinis dapat dilanjutkan setelah penelitian ini.

\section{DAFTAR KEPUSTAKAAN}

1. Salzmann J, Limb A, Khaw P. Matrix metalloproteinases and their Natural Inhibitors in Fibrovascular Membranes of Proliferative Diabetic Retinopathy. Br J Ophthalmology 2002; 84: 1091-1096

2. Lambert V, Munaut C, Jost M. Matrix Metalloproteinase-9 Contributes to Choroidal Neovascularization. American Journal of Pathology 2002; 161: 1247-1253

3. Das A, McLamore A, Song W. Retinal Neovascularization is Supressed with a Matrix metalloproteinase Inhibitor. Archives of Ophthalmology. 1999; 117: 498-503

4. Pepper M. Role of the Matrix metalloproteinase and Plasminogen Activator-Plasmin Systems in Angiogenesis. Arteriosclerosis, Thrombosis, and Vascular Biology. 2001;21: 1104

5. Milhavet O, Gary D, Mattson M. RNA Interference in Biology and Medicine. Pharmacological Reviews.2003;55: 629-648

6. Edelman JL, Lutz D, Castro MR. Corticosteroids inhibit VEGF-induced vascular leakage in a rabbit model of blood retinal and blood aqueous barrier breakdown. Exp Eye Research. 2005;80(2): 249-258.

7. Stetler-Stevenson WG. Matrix metalloproteinase in Angiogenesis: a moving target for Therapeutic Intervention. Journal of Clinical Investigation. $1999 ; 103: 1237-1241$

8. Ehelrs N. Metalloproteinases. Department of Ophthalmology University of the Witwatersrand. January 2001 Available on http://www.health.wits.ac.za/ophthalmology/opjan01.htm

9. Sethi. Matrix metalloproteinase Biology applied to Vitreoretinal Disorders. Br J Ophthalmology 2000;84: 654-666 